\title{
After the Decline: What Maintains Low Winter Moth Density after Successful Biological Control?
}

\author{
Jens Roland
}

The Journal of Animal Ecology, Vol. 63, No. 2. (Apr., 1994), pp. 392-398.

Stable URL:

http://links.jstor.org/sici?sici=0021-8790\%28199404\%2963\%3A2\%3C392\%3AATDWML\%3E2.0.CO\%3B2-3

The Journal of Animal Ecology is currently published by British Ecological Society.

Your use of the JSTOR archive indicates your acceptance of JSTOR's Terms and Conditions of Use, available at http://www.jstor.org/about/terms.html. JSTOR's Terms and Conditions of Use provides, in part, that unless you have obtained prior permission, you may not download an entire issue of a journal or multiple copies of articles, and you may use content in the JSTOR archive only for your personal, non-commercial use.

Please contact the publisher regarding any further use of this work. Publisher contact information may be obtained at http://www.jstor.org/journals/briteco.html.

Each copy of any part of a JSTOR transmission must contain the same copyright notice that appears on the screen or printed page of such transmission.

The JSTOR Archive is a trusted digital repository providing for long-term preservation and access to leading academic journals and scholarly literature from around the world. The Archive is supported by libraries, scholarly societies, publishers, and foundations. It is an initiative of JSTOR, a not-for-profit organization with a mission to help the scholarly community take advantage of advances in technology. For more information regarding JSTOR, please contact support@ jstor.org. 
Journal of Animal

Ecology 1994,

63, 392-398

\title{
After the decline : what maintains low winter moth density after successful biological control?
}

\author{
JENS ROLAND \\ Department of Zoology, University of Alberta, Edmonton, Alberta, Canada T6G 2E9, and, Forestry Canada \\ Ontario Region, 1219 Queen Street East, Sault Ste. Marie, Ontario, Canada P6A 5M7
}

\begin{abstract}
Summary
1. Life-table data for winter moth are analysed for an 8-year period following introduction of parasitoids for biological control in British Columbia, Canada.

2. Winter moth density declined in 1984, and has remained low since 1985 at an average density of approximately 1.20 adults per $\mathrm{m}^{2}$.

3. Introduced parasitoids contributed to mortality during the decline, and have a weak, delayed density-dependent effect at the new low density.

4. Mortality of unparasitized pupae in the soil (primarily by predation) is strongly, and directly density-dependent at the new low density, and is the factor which is most strongly regulatory.

5. Analysis indicates that the strong regulation of winter moth numbers by generalist predators allows parasitism levels to vary greatly after suppression without the eruption of winter moth populations ; if parasitism were absent, winter moth populations would erupt to pre-biocontrol levels.
\end{abstract}

Key-words : biological control, winter moth, Operophtera brumata, life-tables, population dynamics, predation, parasitism.

Journal of Animal Ecology (1994) 63, 392-398

\section{Introduction}

Successful biological control of insects consists of two components: the suppression of pest insect abundance and the maintenance of low density following suppression. Those factors which cause suppression may not be those which maintain insect numbers at a low level. The number of studies which examine the relative impact of mortality factors during both suppression and at low density in successful biological control, are few (e.g. Ives 1976; Murdoch et al. 1984; Ryan 1990).

One of the most dramatic successes of classical biological control of forest insects is that of introduced winter moth, Operophtera brumata (L.) (Lepidoptera : Geometridae), in oakwoods in Nova Scotia by the introduced tachinid fly Cyzenis albicans (Fall.) and the ichneumonid wasp Agrypon flaveolatum (Grav.) (Embree 1965, 1966). Populations of winter moth declined in 1961-63, a few years after parasitoid introduction. Although winter moth still occur at outbreak levels in apple orchards in Nova Scotia (MacPhee, Newton \& McRae 1988, Embree 1991), they are currently at very low levels in oakwoods (Embree 1991). The factors maintaining these low levels in oakwoods are not known, but have been generally assumed to be due to the introduced biological control agents (Hassell 1980; Murdoch, Chesson \& Chesson 1985; Embree 1991). Control of winter moth in Nova Scotia has been cited in the debate over the mechanism by which introduced parasitoids maintain low host numbers. The controversy centres over whether stability occurs by aggregative attack by parasitoids (Hassell 1980), or by local extinction and re-invasion by host and parasite (Murdoch et al. 1985). Unfortunately, no life-table data are available for winter moth in Nova Scotia oakwoods after the year of population collapse to determine either the major factor maintaining low density there, or the mechanism by which they operate.

Studies of native winter moth populations in Britain (Varley \& Gradwell 1958), were initiated specifically to examine the role of natural enemies in the regulation of an endemic defoliator. In that population, there was little impact by parasitoids, including Cyzenis albicans. Pupal mortality in the soil was the single most important regulatory factor (i.e. density-dependent among generations) (Varley \& Gradwell 1968; East 1974).

A more recent introduction of winter moth on southern Vancouver Island, British Columbia (Gillespie et al. 1978), and a subsequent introduction of 
C. albicans and A. flaveolatum for biological control (Embree \& Otvos 1984), has also resulted in decline of the pest. Life-table studies during decline of winter moth in British Columbia (Roland 1988, 1990a) showed that introduced agents added significant mortality during population decline. There was also a concurrent large rise in pupal mortality caused by predators in the soil (Roland 1988, 1990a, but see Embree 1991). The rise in pupal mortality during decline was due, in part, to very strong interaction between parasitism and predation resulting in their combined effect being greater than if they acted independently (Roland 1990a). I continued life-table studies in British Columbia until 1990 (6 years past the year of decline) with a view to identifying the processes maintaining low density after suppression. Here I describe the results of these 'post-decline' studies, and compare them with life-table data from introduced populations at Oak Hill, Nova Scotia (Embree 1965) and with native winter moth populations at Wytham Wood, Britain (Varley, Gradwell \& Hassell 1973).

\section{Methods}

The biology of winter moth has been described extensively elsewhere (Embree 1965; Frank 1967; Varley \& Gradwell 1968; Hassell 1968, 1980; Varley et al. 1973; East 1974). The winter moth life cycle is characterized by: (i) an over-wintering egg stage (November-April); (ii) early spring hatch of larvae and its synchrony with timing of budburst (MarchApril); (iii) a long period of pupation in the soil during summer and autumn (May-November); and (iv) emergence of adults from the soil in late November, the females of which are flightless. Both species of introduced parasitoids attack winter moth in the late larval stage and pupate within the host after the host has itself pupated in the soil. Although winter moth adults emerge from the soil in November, the introduced parasitoids remain in the host cocoon, in the soil, until the following April.

\section{STUDY SITES}

Life-table studies were conducted primarily at $\mathrm{Mt}$. Tolmie Park, Victoria, on southern Vancouver Island, British Columbia, from 1982 to 1990. This site is dominated by Garry oak Quercus garryana Douglas, ranging in height from 2 to $5 \mathrm{~m}$. Parasitism rates were also estimated at four additional oak sites on Saanich Peninsula, southern Vancouver Island, from 1983 to 1987 (sites described in Roland 1986). Predation rates were also estimated at these additional sites in 1987.

\section{LIFE-TABLE STUDIES}

Abundance of four life-stages of the winter moth were estimated in 16 trees each year from 1982 to 1990. Methods used at each stage were similar to those used in Britain (Varley et al. 1973) and in Nova Scotia (Embree 1965) :

\section{Adults}

Up until 1986, flightless females were trapped on tree trunks using stocking traps (Embree 1965). After 1986, I used sticky traps to trap females. Because sticky traps removed all females ascending trees, new trees were selected each year for density estimates that year. Using new trees each year assumed that egg density in the 16 new trees was, on average, the same as would have been laid on the 16 trees on which females were trapped the previous autumn. The stand had over 500 oak trees, so removal of winter moth from 16 trees each year probably had little effect on overall density. Density of females was expressed per $\mathrm{m}^{2}$ of tree canopy and was multiplied by two to give adult density (assuming 1:1 sex ratio).

\section{Eggs}

Fecundity was estimated from dissection of females or from pupal weights, and the relationship between pupal weight and fecundity (Roland \& Myers 1987).

\section{Pupae}

Density of all pupae entering the soil was estimated using peat-filled pupation trays set under each tree (Roland 1988), into which winter moth prepupae drop and readily pupate.

\section{Unparasitized pupae}

The number of winter moth escaping parasitism was determined by opening cocoons from the pupation trays and scoring whether or not they were parasitized, and by which parasitoid. All densities were transformed to base-10 logarithms.

\section{MORTALITY ESTIMATES}

The magnitude of mortality during each life stage was calculated as $k$-values (Varley et al. 1973). Reduction from maximum fecundity $k_{\text {fec }}$ was estimated from the difference between log of the greatest mean fecundity of moths observed among the 8 years of study, and the log of mean fecundity observed in each year. Egg and larval mortality $k_{\text {larv }}$ was estimated as the difference between the log of mean egg potential per $\mathrm{m}^{2}$ in each year and the mean density of all prepupae per $\mathrm{m}^{2}$ entering pupation trays. Mortality from parasitism $k_{\text {par }}$ was the difference between log mean density of prepupae entering the soil, and the log of the density of those which were unparasitized. Pupal mortality $k_{\text {pupa }}$ was the difference between log-density of unparasitized prepupae dropping in May and the density of emerging winter moth adults in November. 
To determine any density-dependent regulatory effect of each mortality factor in the British Columbia population, $k$-values were plotted against the log-density of the stage on which that mortality acted (Varley et al. 1973). The exception was losses due to reduced fecundity of females emerging in autumn, $k_{\text {fec }}$, which was plotted against density of eggs in the previous spring. This was done with the assumption that reduction in fecundity at high density results largely from food limitation of larvae in the previous spring. $K$-values for populations at Oak Hill, Nova Scotia were similarly plotted for comparison. Densities at Oak Hill were adjusted downward to account for the larger trees (greater number of insects per $\mathrm{m}^{2}$ of ground), compared to Mt. Tolmie (D.G. Embree, personal communication). To determine any delayed density-dependent pattern of mortality, the magnitude of each $k$-value was also regressed against log density in the preceding year for the appropriate stage.

Parasitism estimates at the four sites in addition to $\mathrm{Mt}$. Tolmie, were obtained from collection and dissection of fully-fed larvae, and counting the Cyzenis maggots in the salivary glands (Hassell 1980). Predation rates were estimated at each of these sites in 1987 by 'planting' and recovery of 100 pupae over the interval from 27 May to 31 October. Fate of pupae in the soil, including any predation, was determined from the recovered pupae (techniques described in Roland 1990a).

\section{POPULATION EQUILIBRIUM}

The rate of population change from one year to the next, $R_{t}$, was calculated as the log of the ratio of adult density in the following year to density in the current year, $\log \left(N_{t+1} / N_{t}\right)$ (Royama 1981). To determine any density-dependence in the rate of population change, and the presence of any equilibria, $R_{t}$ was plotted as a function of $\log N_{t}$ (Berryman, Stenseth \& Isaev 1987).

\section{Results}

FECUNDITY, $k_{\text {fec }}$

Fecundity averaged $84(\mathrm{SE} \pm 10 \cdot 0)$ eggs per female (42 per adult) in 1983 when populations were at outbreak level. The maximum mean winter moth fecundity observed in any year was $252(\mathrm{SE} \pm 5 \cdot 5)$ eggs per female (126 eggs per adult) in 1990. Reduction in fecundity was density-dependent over all densities (slope $\left.=0.38, r^{2}=0.95, P<0.0001\right)$ (Fig. 1a) and has remained weakly so since 1985 , the year of population collapse (Table 1). There was no relationship between density in the previous year and current year fecundity (Table 1).
EGG AND LARVAL MORTALITY, $k_{\text {larv }}$

Mortality of eggs and larvae at Mt. Tolmie was very high while winter moth was in the epidemic stage of its outbreak (Fig. 1b). At high density many trees were virtually totally defoliated, probably resulting in competition among larvae for food, and causing starvation and failure to pupate. Predation on larvae by birds was also high, and inflicted high local mortality on winter moth (Roland, Hannon \& Smith 1986). There is no indication that egg and larval mortality are regulating winter moth at low density at Mt. Tolmie by either a direct or delayed mechanism (Table 1). In Nova Scotia, mortality of eggs and larvae was also very high prior to parasitoid introduction (Embree 1965) and was strongly density-dependent (Fig. 1b). There is no indication that the low density observed now in Nova Scotia, is being maintained by these factors (Fig. 1b).

PARASITISM, $k_{\mathrm{par}}$

At Mt. Tolmie, parasitism by introduced parasitoids rose over a period of 4-5 years following their introduction, reaching a peak of $80 \%$ in 1984 and 1985 (Fig. 1c). At two of the other sites on Vancouver Island (Senanus Road and Stelly's Cross Road), parasitism peaked at $60-80 \%$ and then declined. By 1987 , parasitism reached $40-50 \%$ at the remaining two sites (Riptide Farm and Downes Road), but had not yet peaked (Table 2). Virtually all parasitism at these sites was by $C$. albicans; the ichneumonid $A$. flaveolatum caused only $1-2 \%$ parasitism, even in the later years of the study. Since 1985, parasitism has fluctuated between 40 and $80 \%$ among years at Mt. Tolmie, without any direct relationship with host density (Fig. 1c, Table 1). There is, however, a significant delayed effect of density on parasitism (Table 1) with a slope of 0.59 . There are no data on parasitism levels in oakwoods after population decline in Nova Scotia (Embree 1991), but in apple orchards they inflict less than 5\% parasitism (MacPhee, Newton \& McRae 1988).

PUPAL MORTALITY, $k_{\text {pupa }}$

Pupal mortality at Mt. Tolmie rose consistently from 1982 through 1985, the period over which winter moth numbers declined (Fig. 1d). Since then, pupal mortality has fallen into a pattern of strong density dependence as a function of density of unparasitized pupae (Fig. 1d). This is the same interval over which winter moth density has remained very stable (Roland 1990a). The slope of the regression of pupal mortality vs pupal density for the 6 years, 1985-90 (slope $=0.87, P=0.07, r^{2}=0.59$ ) suggests that mortality of pupae can, by itself, regulate winter moth at 

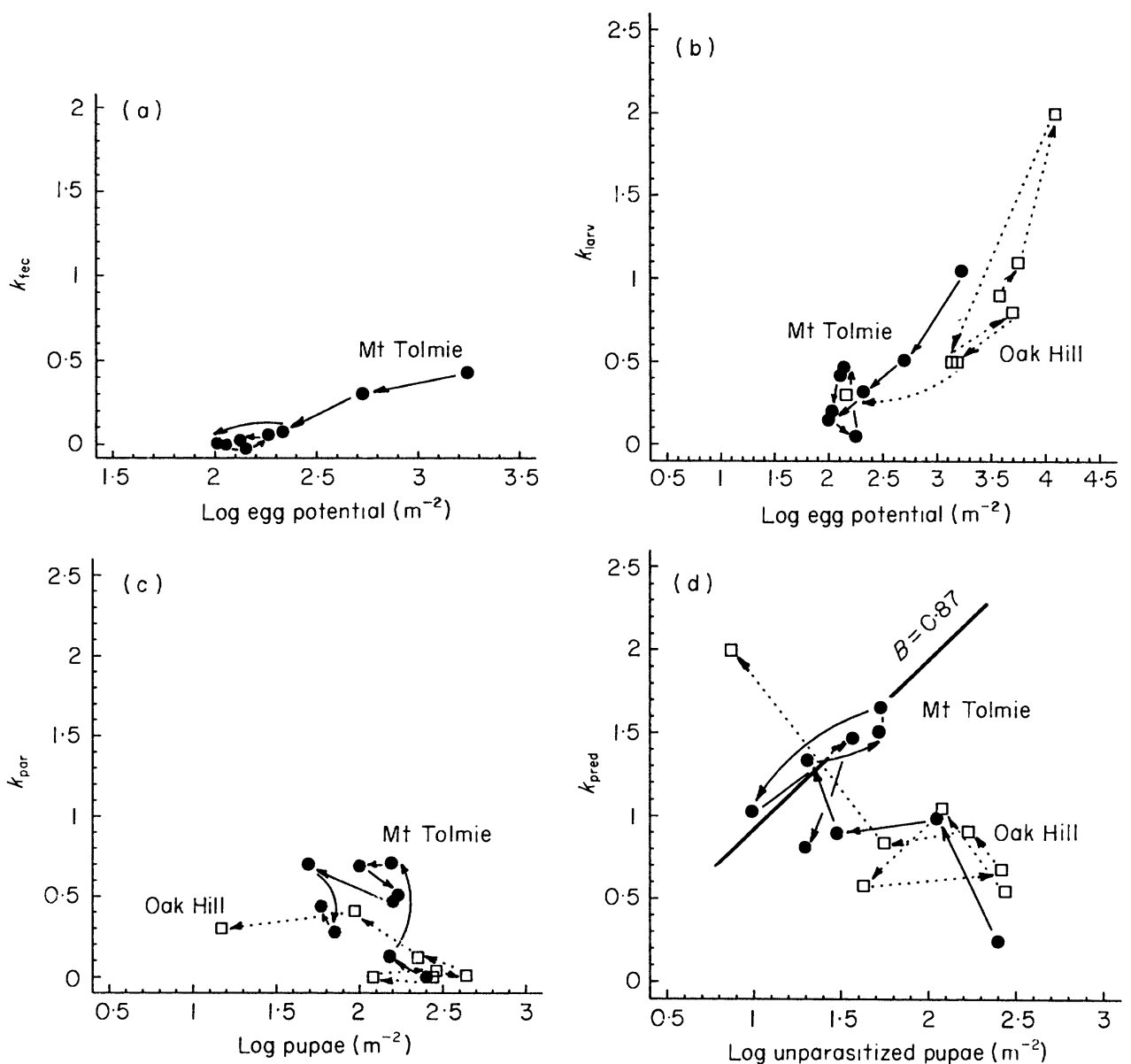

Fig. 1. Mortality ( $k$-values) as a function of density on which each factor acts, for both Mt. Tolmie, British Columbia ( and Oak Hill, Nova Scotia ( $\square$ ) : (a) reduction in fecundity; (b) egg and larval mortality; (c) parasitism by C. albicans and A. flaveolatum; and (d) pupal mortality in the soil. Nova Scotia data provided by D.G. Embree.

Table 1. Relationship between each mortality estimate and the density on which each is acting at both Mt. Tolmie Park, Victoria and Wytham Wood, Berkshire. Mortality was regressed against density in the current year, and against density in the previous year. Wytham Wood data on reduced fecundity from Gradwell (1974), and for the other mortality factors from Varley, Gradwell \& Hassell, 1973, p. 201

\begin{tabular}{|c|c|c|c|c|}
\hline & \multicolumn{2}{|l|}{ No lag } & \multicolumn{2}{|c|}{ 1-year lag } \\
\hline & Slope & $r^{2}$ & Slope & $r^{2}$ \\
\hline \multicolumn{5}{|c|}{ Mt Tolmie 1985-90 } \\
\hline$k_{\mathrm{fec}}$ & $0.22 *$ & 0.58 & 0.09 & $0 \cdot 39$ \\
\hline$k_{\text {larv }}$ & 0.06 & 0.00 & $0 \cdot 10$ & $0 \cdot 02$ \\
\hline$k_{\mathrm{par}}$ & -0.06 & 0.01 & $0.59 \dagger$ & $0 \cdot 67$ \\
\hline$k_{\text {pred }}$ & $0 \cdot 88^{*}$ & 0.59 & $-0 \cdot 37$ & $0 \cdot 10$ \\
\hline$k_{\text {pred }} 1985-89$ & $0.73 \ddagger$ & 0.94 & -0.22 & $0 \cdot 08$ \\
\hline \multicolumn{5}{|c|}{ Wytham Wood 1950-68 } \\
\hline$k_{\mathrm{fec}}$ & $0 \cdot 10 \ddagger$ & 0.43 & 0.02 & 0.02 \\
\hline$k_{\text {larv }}$ & $0 \cdot 16$ & 0.04 & $-0 \cdot 07$ & 0.01 \\
\hline$k_{\mathrm{par}}$ & $0 \cdot 01$ & 0.01 & $0.03 *$ & $0 \cdot 21$ \\
\hline$k_{\text {pred }}$ & $0 \cdot 32 \S$ & 0.58 & $0 \cdot 31 \ddagger$ & $0 \cdot 48$ \\
\hline
\end{tabular}

$* P<0 \cdot 10 ; \dagger P<0.05 ; \ddagger P<0.01 ; \S P<0.001$. low densities. For the 5-year interval 1985-89, this relationship had a slightly lower slope (slope $=0.73$, $P=0.006$ ), but there was virtually no deviation from this regression among the 5 years $\left(r^{2}=0.94\right)$. The pattern of strong unlagged density dependence suggests a rapid functional response by predators to yearly changes in abundance of winter moth as prey, rather than a numerical response through changes in reproduction. There is no pattern of delayed density dependence of pupal mortality at Mt. Tolmie. At the other four sites on Vancouver Island, predation rates ranged between 89 and 94\% in 1987 (Table 2) levels similar to that observed from life table data from Mt. Tolmie and from 'planting' of pupae (Roland 1990a).

At Oak Hill, Nova Scotia, pupal mortality rose dramatically during the decline, but no data were collected after the population collapse to determine any regulatory pattern with density. In both populations in Canada, rate of predation on pupae rose to 90-98\%, much higher than that observed at Wytham Wood (50-85\%). 

stability

Table 2. Parasitism rates ( $n$ ) from 1983-87 at five sites on Saanich Peninsula, southern Vancouver Island, and predation rates (n) in 1987 for the same sites

\begin{tabular}{|c|c|c|c|c|c|c|c|c|c|c|}
\hline \multirow{2}{*}{$\begin{array}{c}\text { Year } \\
1982\end{array}$} & \multicolumn{2}{|c|}{$\begin{array}{l}\text { 1. Riptide } \\
\text { Farm }\end{array}$} & \multicolumn{2}{|c|}{$\begin{array}{l}\text { 2. Downes } \\
\text { Road }\end{array}$} & \multicolumn{2}{|c|}{$\begin{array}{l}\text { 3. Senanus } \\
\text { Road }\end{array}$} & \multicolumn{2}{|c|}{$\begin{array}{l}\text { 4. Stelly's } \\
\text { Cross Road }\end{array}$} & \multicolumn{2}{|c|}{$\begin{array}{l}\text { 5. Mt Tolmie } \\
\text { Park }\end{array}$} \\
\hline & & & & & & & & & 0.00 & (99) \\
\hline 1983 & & & & & & & & & 0.25 & (1587) \\
\hline 1984 & 0.00 & (161) & $0 \cdot 04$ & (116) & $0 \cdot 20$ & (65) & $0 \cdot 37$ & (115) & 0.67 & (1066) \\
\hline 1985 & 0.07 & $(28)$ & $0 \cdot 20$ & $(55)$ & 0.65 & (17) & 0.79 & $(47)$ & 0.84 & $(410)$ \\
\hline 1986 & $0 \cdot 22$ & (101) & $0 \cdot 34$ & (109) & $0 \cdot 35$ & (43) & 0.59 & $(108)$ & 0.58 & (703) \\
\hline 1987 & $0 \cdot 43$ & $(51)$ & $0 \cdot 50$ & (106) & - & & 0.43 & $(51)$ & $0 \cdot 81$ & (502) \\
\hline 1987 predation & 0.94 & (80) & 0.94 & $(80)$ & 0.89 & (80) & 0.90 & (80) & 0.96 & $(80)$ \\
\hline
\end{tabular}

\section{POPULATION EQUILIBRIUM}

At the present rates of reproduction and mortality, the winter moth population at Mt. Tolmie has a calculated equilibrium density $\left(R_{t}=0 \cdot 0\right)$ of approximately 1.20 adults per $\mathrm{m}^{2}$ (Fig. 2). The trajectory of the rate of population change over time (Fig. 2) is characterized by a declining population from 1982 to 1984 resulting from starvation, increased parasitism and increased predation. From 1985 to 1989, the Mt. Tolmie population has settled into a strong pattern of density-dependence, due largely to the pattern of strong (and rapid) density-dependent pupal mortality described above (Fig. 1). There is no indication that variation in fecundity (Fig. 1a), egg or larval mortality (Fig. 1b) are regulatory at low density (Table 1). The slower response of parasitism to changes in abundance at low density (lagged density dependence) could cause oscillation about the calculated equilibrium in future years, as suggested by Fig. 2 (dashed line).

\section{Discussion}

Eight years of life-table data on pre- and post-decline dynamics of introduced winter moth in British Col-

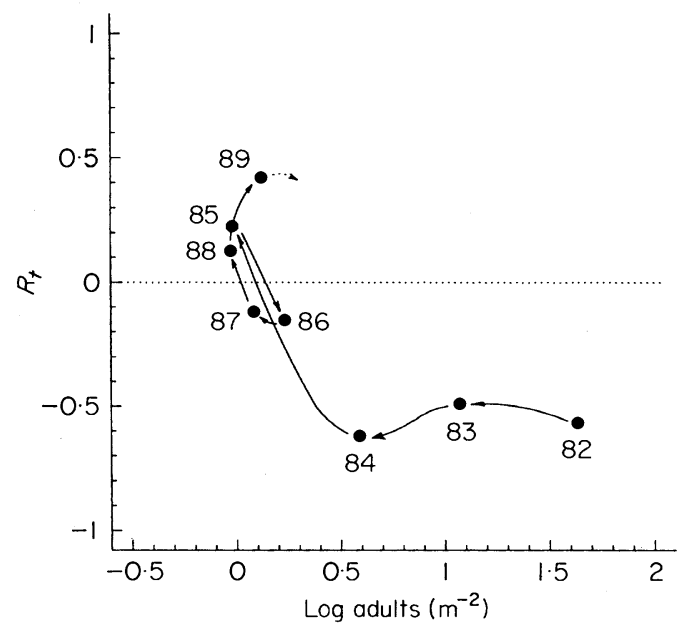

Fig. 2. Trajectory of rate of population change $R_{t}$ as a function of log adult density in each year (1982-90). umbia are interpreted in light of the vast knowledge of the biology of winter moth and of their natural enemies (East 1974; Embree 1965, 1966, 1991; Frank 1967; Hassell 1980; Kowolski 1977; MacPhee et al. 1988; Roland 1988, 1990a, 1990b; Varley \& Gradwell 1968). The endemic winter moth population in Wytham Wood (Varley et al. 1973) was regulated principally by predation of pupae in the soil by generalist beetle predators (East 1974; Frank 1967; Kowolski 1976). Although parasites contributed some mortality to native winter moth populations in Britain, and were present each year, they had no regulatory effect there. In the two populations under biological control in Canada, parasitism rose to 40 $80 \%$ and then declined as host density declined (Embree 1966; Roland 1988). In Nova Scotia, parasitism was assumed to keep host density low after decline (Embree 1991; Hassell 1980). In British Columbia, introduced parasitoids, almost exclusively Cyzenis albicans, have added mortality to the winter moth system, but parasitism levels peaked at intermediate host density during the decline (Roland 1990a), and showed a weaker (slope $=0.59$ ) lagged ability to be regulatory over the period that host numbers have stabilized (Fig. 1c). In Nova Scotia, parasitism rose to levels similar to those observed in British Columbia (Fig. 1c), but there are no life-table data to determine their role in maintaining the new low density in oakwoods (Embree 1991). The fact that introduced parasites are present at low density in both Nova Scotia (Embree 1991) and in British Columbia, does not mean that they are responsible for holding host numbers low.

Predation on pupae in the soil rose sharply during decline in both Nova Scotia (Embree 1965) and British Columbia (Roland 1988) to levels higher than recorded at Wytham Wood (Varley et al. 1973). At low density, pupal mortality is strongly regulatory in the two populations for which there are data (Wytham Wood [Varley et al. 1973] and British Columbia [this paper]).

\section{POPULATION EQUILIBRIUM}

The shape of the population growth curve (Fig. 3) provides an indication of the potential for future out- 


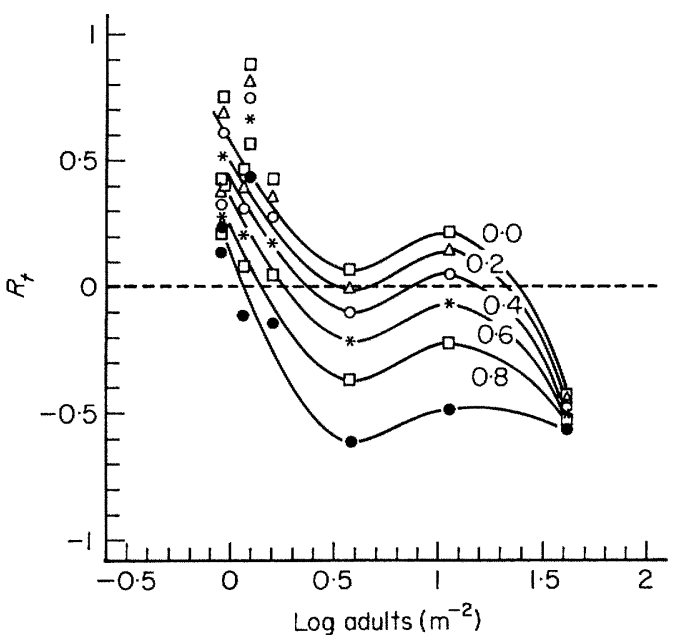

Fig. 3. Rate of population change $R_{t}$ as a function of log adult density in each year (1982-89). $R_{t}$ is calculated with observed levels of parasitism (O), and with decreased proportion of observed parasitism in each year. Lines are fitted by eye.

breaks if there was a reduction in the level of parasitism. Parasitism could decline because of hyperparasitism of C. albicans (e.g. Humble 1985), increase in other mortality of the parasitoid, poor host-parasitoid synchrony because of unusual weather, or by ingestion of Cyzenis eggs on foliage by other defoliators (Embree 1991). I have evaluated the effect of reduced parasitism on population dynamics by decrementing the level of parasitism observed each year and re-calculating rate of population change, $R_{t}$. These calculations assume that parasitism is independent of other mortality factors. Reduction in parasitism to as little as 0.4 times their observed value in each year would have little effect on equilibrium density (Fig. 3) because of the strong density-dependent pupal mortality keeping density low. Parasitism can, therefore, vary a great deal (shifts in elevation of the curve in Fig. 3) without substantial winter moth outbreak. This may explain the uniform success of the biological control over large areas of Nova Scotia (Embree 1991) and British Columbia, despite great spatial variation in levels of parasitism attained in both studies (Embree 1965; Roland 1986, 1990b). Parasitism would have to be reduced to $0 \cdot 2-0 \cdot 3$ times their observed values to raise the $R_{t}$ curve to the level that virtually ensures winter moth outbreak (Fig. 3). If parasitoids were not present (such as prior to their introduction), the equilibrium density is estimated at approximately 25 adults per $\mathrm{m}^{2}(\log =1.4$; upper curve in Fig. 3). The above pattern suggests that further improvement to biological control of winter moth should not be directed towards increasing parasitoid efficiency (as suggested by Roland, Evans \& Myers 1989). Rather, efforts would be best directed at maintaining high pupal mortality. High densities of winter moth observed in commercial orchards in the presence of Cyzenis albicans (Roland 1986; MacPhee et al. 1988) may result, in part, from pesticide use which reduces the abundance of soil-dwelling predators. Population models of biological control of winter moth, which attribute the maintenance of low host density to the parasitoid (Hassell 1980), assumed that pupal mortality in the soil was constant and unrelated to pupal density, which it is not.

The mechanism I have described for suppression and maintenance of low winter moth density implies that there was a single, high-density equilibrium of winter moth prior to parasite introduction (uppermost curve, Fig. 3), and that populations have now shifted to a lower equilibrium maintained by predation on pupae (lowermost curve, Fig. 3). The switch between the two equilibria was no doubt aided by introduced parasitoids and, as described elsewhere (Roland 1988, 1990a), by the increased impact of predation through its interaction with parasitism (higher rates of predation on unparasitized pupae). Debate over possible mechanisms by which introduced parasitoids stabilize winter moth populations under biological control (Hassell 1980; Murdoch et al. 1985) assumes that parasites are in fact the cause of low-density regulation. The debate, with respect to winter moth, may be more appropriately directed at the impact of generalist predators on the pupal stage. In the winter moth system predation is strongly density-dependent, both within generations (Roland 1990b) and among generations as shown here. Predation, virtually by itself, can regulate winter moth numbers in this population.

\section{Conclusion}

As time progresses, the pattern of population dynamics in British Columbia resembles more closely that at Wytham Wood. Data presented here indicate that the maintenance of low winter moth density in British Columbia, after suppression, results from the magnitude and pattern of pupal mortality caused by generalist predators and from a weaker, delayed densitydependent pattern of parasitism by the introduced parasites. The principal contribution of introduced parasites has been to add mortality to the system, reducing the prey base of unparasitized pupae down to the level at which background predation by generalists can hold the population at the new, lower equilibrium.

Results presented here provide an interpretation which is consistent with data from the other two principal winter moth population studies : the regulatory capability of predation at Wytham Wood (Varley 1970), the increased importance of both parasitism and predation during decline in Nova Scotia (Embree 1965), and the uniform success of controlling winter moth in oakwoods regardless of level of parasitism attained by introduced parasitoids in different populations. 


\section{Acknowledgements}

Field studies were assisted by Angela Hale, Dean Morewood and Troy Danyk. Helpful discussion at various stages of this work were provided by Alan Berryman, Rob Bourchier, Doug Embree, Susan Hannon, Mike Hassell, Judy Myers and Vince Nealis. Doug Embree kindly provided life-table data for Nova Scotia.

\section{References}

Berryman, A.A., Stenseth, N. C. \& Isaev, A.S. (1987) Natural regulation of herbivorous forest insect populations. Oecologia, 71, 174-184.

East, R. (1974) Predation on the soil dwelling stages of the winter moth at Wytham Wood, Berkshire. Journal of Animal Ecology, 43, 611-626.

Embree, D.G. (1965) The population dynamics of the winter moth in Nova Scotia, 1954-1962. Memoirs of the Entomological Society of Canada, 46, 1-57.

Embree, D.G. (1966) The role of introduced parasites in the control of the winter moth in Nova Scotia. Canadian Entomologist, 98, 1159-1168.

Embree, D.G. \& Otvos, I.S. (1984) Operophtera brumata (L.) winter moth (Lepidoptera: Geometridae). Biological Control Programmes Against Insects and Weeds in Canada, 1969-80 (eds J.S. Kelleher \& M.A. Hulme), pp. 353-357. Commonwealth Agricultural Bureaux, Slough.

Embree, D.G. (1991) The winter moth Operophtera brumata in eastern Canada, 1962-1988. Forest Ecology and Management, 39, 47-54.

Frank, J.H. (1967) The insect predators of the pupal stage of the winter moth, Operophtera brumata (L.) (Lepidoptera : Hydriomenidae). Journal of Animal Ecology, 36, 375-389.

Gillespie, D.R., Finlayson, T., Tonks, N.V. \& Ross, D.A. (1978) Occurrence of the winter moth, Operophtera brumata (Lepidoptera: Geometridae), on southern Vancouver Island, British Columbia. Canadian Entomologist, 110, 223-224.

Gradwell, G.R. (1974) The effect of defoliators on tree growth. The British Oak (eds M.G. Morris \& F.H. Perring), pp. 182-193. E.W. Classey, Faringdon.

Hassell, M.P. (1968) The behavioural response of a tachinid fly (Cyzenis albicans (Fall.)) to its host, the winter moth (Operophtera brumata (L.)). Journal of Animal Ecology, 37, 627-639.

Hassell, M.P. (1980). Foraging strategies, population models and biological control: a case study. Journal of Animal Ecology, 49, 603-628.

Humble, L.M. (1985) Final-instar larvae of native pupal parasites and hyperparasites of Operophtera spp. (Lepidoptera: Geometridae) on southern Vancouver Island. Canadian Entomologist, 117, 525-534.

Ives, W.G.H. (1976) The dynamics of larch sawfly (Hymenoptera: Tenthredinidae) populations in southeastern Manitoba. Canadian Entomologist, 108, 701-730.

Kowolski, R. (1976) Biology of Philonthus decorus (Coleoptera : Staphylinidae) in relation to its role as a predator of winter moth pupae [Operophtera brumata (Lepidoptera : Geometridae)]. Pedobiologia, 16, 233-242.

MacPhee, A., Newton, A. \& McRae, K.B. (1988) Population studies on the winter moth Operophtera brumata (L.) (Lepidoptera: Geometridae) in apple orchards in Nova Scotia. Canadian Entomologist, 120, 73-83.

Murdoch, W.W., Reeve, J.D., Huffaker, C.B. \& Kennett, C.E. (1984) Biological control of scale insects and ecological theory. American Naturalist, 123, 371-392.

Murdoch, W.W., Chesson, J. \& Chesson, P.L. (1985) Biological control in theory and practice. American Naturalist, 125, 344-366.

Roland, J. (1986) Parasitism of winter moth in British Columbia during build-up of its parasitoid Cyzenis albicans: attack rate on oak vs. apple. Journal of Animal Ecology, $\mathbf{5 5}, 215-234$.

Roland, J. (1988) Decline of winter moth populations in North America : direct versus indirect effect of introduced parasites. Journal of Animal Ecology, 57, 523-531.

Roland, J. (1990a) Interaction of parasitism and predation in the decline of winter moth in Canada. Population Dynamics of Forest Insects (eds A.D. Watt, S.R. Leather, M.D. Hunter \& N.A.C. Kidd), pp. 289-302. Intercept Ltd, Andover.

Roland, J. (1990b) Parasitoid aggregation : chemical ecology and population dynamics. Critical Issues in Biological Control (eds M. Mackauer, L.E. Ehler \& J. Roland), pp. 185-211. Intercept Ltd, Andover.

Roland, J., Hannon, S.J. \& Smith, M.A. (1986) Foraging pattern of pine siskins and its influence on winter moth survival in an apple orchard. Oecologia, 69, 47-52.

Roland, J. \& Myers, J.H. (1987) Improved insect performance from host-plant defoliation : winter moth on oak and apple. Ecological Entomology, 12, 409-414.

Roland, J., Evans, W.G. \& Myers, J.H. (1989) Manipulation of oviposition patterns of the parasitoid Cyzenis albicans (Tachinidae) in the field using plant extracts. Journal of Insect Behavior, 2, 487-503.

Royama, T. (1981) Fundamental concepts and methodology for the analysis of animal population dynamics, with particular reference to univoltine species. Ecological Monographs, 51, 473-493.

Ryan, R.B. (1990) Evaluation of biological control: introduced parasites of larch casebearer (Lepidoptera: Coleophoridae) in Oregon. Environmental Entomology, 19, 1873-1881.

Varley, G.G. (1970) The effects of natural predators and parasites on winter moth populations in England. Proceedings of the Tall Timbers Conference on Ecological Animal Control by Habitat Management No. 2, Tallahassee Florida, 103-116.

Varley, G.G. \& Gradwell, G.R. (1958) Oak defoliators in England. Proceedings of the 10th International Congress of Entomology, 4, 133-136.

Varley, G.G. \& Gradwell, G.R. (1968) Population models for the winter moth. Insect Abundance (ed. T.R.E. Southwood), pp. 132-142. Blackwell Scientific, Oxford.

Varley, G.G., Gradwell, G.R. \& Hassell, M.P. (1973) Insect Population Ecology. University of California Press, Berkeley.

Received 28 August 1992 ; revision received 4 June 1993 
http://www.jstor.org

\section{LINKED CITATIONS}

- Page 1 of 2 -

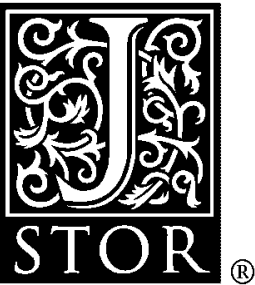

You have printed the following article:

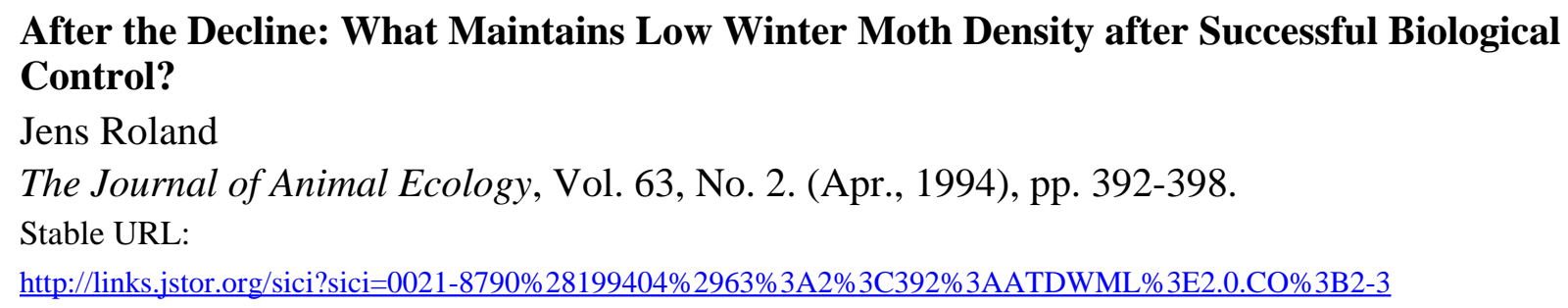

After the Decline: What Maintains Low Winter Moth Density after Successful Biological Control?

Jens Roland

The Journal of Animal Ecology, Vol. 63, No. 2. (Apr., 1994), pp. 392-398.

Stable URL:

http://links.jstor.org/sici?sici=0021-8790\%28199404\%2963\%3A2\%3C392\%3AATDWML\%3E2.0.CO\%3B2-3

This article references the following linked citations. If you are trying to access articles from an off-campus location, you may be required to first logon via your library web site to access JSTOR. Please visit your library's website or contact a librarian to learn about options for remote access to JSTOR.

\section{References}

Predation on the Soil-Dwelling Stages of the Winter Moth at Wytham Woods, Berkshire R. East

The Journal of Animal Ecology, Vol. 43, No. 3. (Oct., 1974), pp. 611-626.

Stable URL:

http://links.jstor.org/sici?sici=0021-8790\%28197410\%2943\%3A3\%3C611\%3APOTSSO\%3E2.0.CO\%3B2-O

The Insect Predators of the Pupal Stage of the Winter Moth, Operophtera brumata (L.) (Lepidoptera: Hydriomenidae)

J. H. Frank

The Journal of Animal Ecology, Vol. 36, No. 2. (Jun., 1967), pp. 375-389.

Stable URL:

http://links.jstor.org/sici?sici=0021-8790\%28196706\%2936\%3A2\%3C375\%3ATIPOTP\%3E2.0.CO\%3B2-7

The Behavioural Response of a Tachinid Fly (Cyzenis albicans (Fall.)) to its Host, the Winter Moth (Operophtera brumata (L.))

M. P. Hassell

The Journal of Animal Ecology, Vol. 37, No. 3. (Oct., 1968), pp. 627-639.

Stable URL:

http://links.jstor.org/sici?sici=0021-8790\%28196810\%2937\%3A3\%3C627\%3ATBROAT\%3E2.0.CO\%3B2-I 
http://www.jstor.org

\section{LINKED CITATIONS}

- Page 2 of 2 -

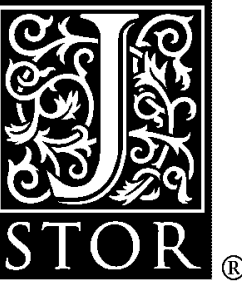

Foraging Strategies, Population Models and Biological Control: A Case Study

Michael P. Hassell

The Journal of Animal Ecology, Vol. 49, No. 2. (Jun., 1980), pp. 603-628.

Stable URL:

http://links.jstor.org/sici?sici=0021-8790\%28198006\%2949\%3A2\%3C603\%3AFSPMAB\%3E2.0.CO\%3B2-H

Biological Control of Olive Scale and Its Relevance to Ecological Theory

William W. Murdoch; John D. Reeve; Carl B. Huffaker; C. E. Kennett

The American Naturalist, Vol. 123, No. 3. (Mar., 1984), pp. 371-392.

Stable URL:

http://links.jstor.org/sici?sici=0003-0147\%28198403\%29123\%3A3\%3C371\%3ABCOOSA\%3E2.0.CO\%3B2-E

Biological Control in Theory and Practice

William W. Murdoch; Jean Chesson; Peter L. Chesson

The American Naturalist, Vol. 125, No. 3. (Mar., 1985), pp. 344-366.

Stable URL:

http://links.jstor.org/sici?sici=0003-0147\%28198503\%29125\%3A3\%3C344\%3ABCITAP\%3E2.0.CO\%3B2-I

Parasitism of Winter Moth in British Columbia During Build-up of its Parasitoid Cyzenis albicans: Attack Rate on Oak V. apple

Jens Roland

The Journal of Animal Ecology, Vol. 55, No. 1. (Feb., 1986), pp. 215-234.

Stable URL:

http://links.jstor.org/sici?sici=0021-8790\%28198602\%2955\%3A1\%3C215\%3APOWMIB\%3E2.0.CO\%3B2-\%23

Decline in Winter Moth Populations in North America: Direct Versus Indirect Effect of Introduced Parasites

Jens Roland

The Journal of Animal Ecology, Vol. 57, No. 2. (Jun., 1988), pp. 523-531.

Stable URL:

http://links.jstor.org/sici?sici=0021-8790\%28198806\%2957\%3A2\%3C523\%3ADIWMPI\%3E2.0.CO\%3B2-D

Fundamental Concepts and Methodology for the Analysis of Animal Population Dynamics, with Particular Reference to Univoltine Species

T. Royama

Ecological Monographs, Vol. 51, No. 4. (Dec., 1981), pp. 473-493.

Stable URL:

http://links.jstor.org/sici?sici=0012-9615\%28198112\%2951\%3A4\%3C473\%3AFCAMFT\%3E2.0.CO\%3B2-S 